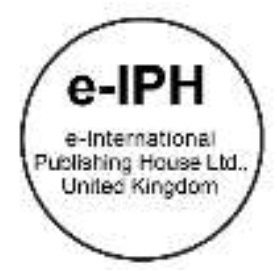

\title{
Attitude towards Safe Driving and Mobile Usage among Young Adult in Malaysia
}

\author{
Mohamad Ghazali Masuri ${ }^{1}$, Nur Atiqah Abdul Samad ${ }^{1}$, Akehsan Dahlan ${ }^{1}$, Khairil Anuar Md Isa ${ }^{2}$ \\ 1 Occupational Therapy Department, \\ ${ }^{2}$ Basic Sciences Department, \\ Faculty of Health Sciences, \\ Universiti Teknologi MARA, Puncak Alam Campus, Selangor, Malaysia \\ atiqahhsamad@gmail.com, zalie222@gmail.com, akehsan.dahlan@yahoo.com, khairil_hpm@hotmail.com \\ Tel: (+60) 017-7709984
}

\begin{abstract}
The purpose of this study is to identify the correlation between driver's attitude and level of internet addiction by using Attitude towards Safe Driving Scale (ASDS-46) and Internet Addiction Test (IAT). The result showed that ASDS-46 and IAT have a high level of reliability of Cronbach's Alpha value 0.910 and 0.917 respectively. Domain 1,2 and 4 (self-compliant, self-confidence and self-concern) show a negative correlation with the value of (P=.000 and -.225$),(P=.019$ and -.111$) \&(P=.044$ and -.095$)$ respectively. This study concludes that driver who has high internet addiction level has a risky behaviour to commit road traffic offenses.
\end{abstract}

Keywords: ASDS-46; internet addiction; driver's attitude; quality of life

eISSN: 2398-4287 @ 2019. The Authors. Published for AMER ABRA cE-Bs by e-International Publishing House, Ltd., UK. This is an open access article under the CC BYNC-ND license (http://creativecommons.org/licenses/by-nc-nd/4.0/). Peer-review under responsibility of AMER (Association of Malaysian Environment-Behaviour Researchers), ABRA (Association of Behavioural Researchers on Asians) and cE-Bs (Centre for Environment-Behaviour Studies), Faculty of Architecture, Planning \& Surveying, Universiti Teknologi MARA, Malaysia. DOI: https://doi.org/10.21834/e-bpj.v4i10.1638

\subsection{Introduction}

The internet is a worldwide system of a computer network where fulfil human needs. Along with the excessive connecting to the internet, someone can be addicted and it is a public health problem (Dieris-Hirche et al., 2017). Shaw and Black (2008) reported that internet addiction is a global phenomenon especially in developed countries of information and technology (IT) with the age range of 20 to 30 . According to Chong Guan, Isa, Hashim, Pillai, \& Harbajan Singh (2012), the internet addiction phenomenon in Malaysia rises drastically over the decade. Simultaneously, the percentage of Malaysia's road traffic accidents (RTA) also has been increased incredibly. The average of annual deaths of road fatalities in recent years is 6, 915 deaths while MIROS' research predicted that in the year of 2020, it will boost up to 10, 716 deaths (Nasa, 2014). Indirectly, it has a powerful effect towards the quality of life of the road users.

A study reported that Malaysia is ranked 19th in the list 25 of countries that have congested internet user (Marlin, 2008). Almost mobile phone has internet connection due to technology advance in order to communicate and socialize (Md Isa et., 2012). The internet access has become universal, acceptable and involves in everyday routine such as driving a car or walking (Błachnio, Przepiorka, SenolDurak, Durak, \& Sherstyuk, 2017). The phenomenon of mobile phone usage while driving in Malaysia is worsen over the years as the existence of messaging applications such as WhatsApp and social media (Augustin, 2017). The mobile phone usage while driving is a serious traffic offense (Md Isa et al., 2012). The situation has become awful when they are using it with the internet access as they are more likely to attach more time and attention towards the mobile phone even when they are driving. This driving behavioural pattern will affect driving performance and contribute to road violate. The Minister of Transportation, Datuk Seri Liow Tiong Lai state that the road

eISSN: 2398-4287 @ 2019. The Authors. Published for AMER ABRA cE-Bs by e-International Publishing House, Ltd., UK. This is an open access article under the CC BYNC-ND license (http://creativecommons.org/licenses/by-nc-nd/4.0). Peer-review under responsibility of AMER (Association of Malaysian Environment-Behaviour Researchers), ABRA (Association of Behavioural Researchers on Asians) and cE-Bs (Centre for Environment-Behaviour Studies), Faculty of Architecture, Planning \& Surveying, Universiti Teknologi MARA, Malaysia. DOI: https://doi.org/10.21834/e-bpj.v4i10.1638 
safety issues become more hazardous when the drivers use the internet access, take pictures and navigate while driving or riding ("Penggunaan telefon bimbit antara punca utama kemalangan jalan raya," 2016).

This issue exists due to the strong attachment between the drivers and their mobile phone that become distracted driving behaviour of using a mobile phone and lead to use social media while driving that will give the adverse effect of driving behaviour of young drivers (Weller, Shackleford, Dieckmann, \& Slovic, 2013). The other current research also states the identical finding. The drivers who use mobile phone with internet access have a high potential to distract while driving (Gauld, Lewis, White, Fleiter, \& Watson, 2017). Hence, these interferences while driving definitely would cause a decrease in the driving performance and lead to RTA and mortality. RTA and injuries are a part of the important problem to the nation and quality of life will be diminished (Masuri, Dahlan, Danis, \& Md Isa, 2017). According to Weinstein \& Lejoyeux (2010), problematic internet addiction leads to functional impairment and marked distress.

However, the number of research and evidence regarding internet addiction and RTA is still limited and has a little attention meanwhile the addicted towards the internet also a part of the factor that contributes to the RTA. Arising of this issue, the gap in the knowledge regarding internet addiction and road traffic accident in Malaysia exists.

\subsection{Literature Review}

\subsection{Attitude towards safe driving}

The statistic of road traffic accident in Malaysia increase 2.8 \% from 467,196 in 2014 to 489, 606 in 2015 (Jabatan Perangkaan Malaysia, 2016) and it keeps arising every year. The main cause that leads to RTA is driving behaviour. This issue is being addressed from all of the motorcyclists and drivers as well as the bus drivers. The commercial buses that have been recorded with high accident percentage and the causes of it has related with human factor such as fatigue, risky driving and speeding where half of the accidents ensue at night in which the drivers used mobile phone while driving (Oluwole, Abdul Rani, \& Rohani, 2015).

The current research showed that the five top of the inappropriate driving behaviour of the driver express buses were passengers alight from the bus not at the assigned terminal, harsh braking, tailgating, using a mobile phone and dangerous overtaking (Ahmad et al., 2017). The aberrant driving behaviour influenced by the other applications of mobile phone as it is compulsory to use it nowadays regardless it is a risky action of driving. The percentage of young adult to use a mobile phone while driving is $66.6 \%$ as they are required to be a multitasker in dealing with a life needs and lead to against the driving rules (Md Isa et al., 2012). According to Pöysti, Rajalin, \& Summala (2005), low skill level and high safety motivation lead to the tendency of using a mobile phone while driving for those who drive for long distance, have more possibility of using mobile phone related hazards.

According to Murad (2014), the Malaysians drivers' poses aberrant attitude which was the primary contributor to the high rate of road fatality opposed with what had been claimed by netizen regarding the unsafe road conditions and vehicles were the factor of it. A study shows that $91 \%$ of the drivers are using text messaging while driving, driving above the speed limit and drifting into different lanes while texting even though they are already knowing all the action is dangerous and illegal (Harrison, 2011).

\subsection{Internet addiction}

Internet addiction is a behaviour problem and give effect to the mental health (Alavi, Maracy, Jannatifard, \& Eslami, 2011). The young adult approximately spends half day to a mobile phone and surf internet. Deputy Multimedia and Communications Minister, Datuk Jailani Johari state that within 12 hours, Malaysians occupied 3 hours 3 minutes were spent on the mobile phone, 5 hours 36 minutes on computers and 3 hours 27 minutes on social media with $98 \%$ of the internet users are active on social media (Kaur, 2015). Calling and texting while driving are common mistakes done by the drivers but now many drivers emerge with more dangerous things as they are connecting to the internet while driving that will cause road fatalities to themselves and other road users.

There are offenses that involve the electronic devices usage which are the drivers take their eyes off the road and hands off the steering to manipulate the mobile phone in order to enable them for dialling, texting and surfing the Web, subsequently they become engaged with the conversations and other applications in the mobile phone in which will impair the driving performances on the road (Insurance Information Institute, 2016). There are the variety of applications in the mobile phone including surf internet and communicate with others through social media such as Facebook that lead to addiction and becomes a culture that will cause road fatalities to the drivers, motorcyclists and even the other road users (Kamarudin, 2011).

About $40 \%$ of driver ages between 18 to 29 take the pictures by using their mobile phone while $23 \%$ between age 18 to 23 years old use it to recording videos while they are on the road (Mendoza, 2015). These factors will lead to road crashes as the total visual and mental process of driving is already lost and this risky driving behaviour will snatch their own and other's life. According to Best (2014), after posting a selfie while driving and updating Facebook moments, a driver had died in the car crashed with a truck. Edelstein (2012) found that the young drivers tend to divide their attention between the road and the web. The web accessing while driving is an aberrant driving behaviour and leads to an adverse outcome such as road traffic crashes (Cook \& Jones, 2011).

Thus, the internet has been associated with the driving performances which contribute to the RTA. It occurs because of the attention withdrawal from the visual scene as driving is an occupation that requires fully participation of the coordination of eye, hand and foot and cognitive ability to maneuver the vehicles. According to Masuri, Dahlan, Danis, and Md Isa (2015), driving is an activity of daily living that requires active eye, hand and foot coordination. The usage of mobile phone while driving cause various kind of distractions such as visual, auditory, manual and cognitive (WHO, 2015). 


\subsection{Quality of life}

Internet act as a connector to reach family members, friends and significant others. The communication and socialization activities occur in every second of their life (Md Isa et al., 2012). Social media is a medium for them to interact and socialize in order to fulfil everyday needs and improve the quality of life (QoL). The adverse effect of the RTA will take account towards the QoL of the road users as it is will provide negative result toward everyday life including physical health, psychological, social relationship and environment. Masuri, Dahlan, Danis, \& Md Isa (2016) reported that the fatal or non-fatal injuries from the previous RTA will cause disability in physical and psychological aspect.

Apart from that, the relationship with the other people will be affected due to low self-confidence and self-esteem to socialize because of the previous or current disability. The psychological consequence of RTA on casualties is post-traumatic stress disorder (PTSD) which will deteriorate the QoL. There is a strong relationship between QoL of the victims and PTSD after one year of the road accident where the financial resources are a part of the factor that has related with poor QoL (Khati et al., 2012). The QoL for the whiplash and mildly injured RTA victims were decline in terms of mental, social and environment due to psychological and socioeconomic factors (Tournier, Hours, Charnay, Chossegros, \& Tardy, 2016). Sitheravellu (2017) found that the majority of the road traffic victims are male sex with the age range between 15 to 44 years old where they are the breadwinners in their family which it leads to tremendous financial problem. Thus, the quality of life status of the family or the victim itself decline.

\subsection{Methodology}

The analytical cross-sectional survey is used as research design to identify the relationship between internet addiction and attitude towards safe driving among young adult users in Malaysia. A simple random sampling is going to be adopted for the study. This study was specifically focusing on the young adult user between 18 to 35 years old in Malaysia which had multi socio-demographic backgrounds.

The self- administering questionnaires of Attitude towards Safe Driving Scale (ASDS-46) is designed to identify the attitude or human factors of a driver while driving and Internet Addiction Test (IAT) is developed to measures the presence and severity of Internet dependency among adults. Both self-administering questionnaires were being conducted by distributed them to the young adult users at the Peninsular Malaysia simultaneously the online survey (Google docs) has been distributed to the public throughout Malaysia.

\subsection{Findings}

A total of 400 questionnaires and Internet-based data collection or online survey (Google docs) were distributed, and only 308 respondents had returned the complete questionnaire and 141 had fulfilled the Google docs. The total participants were 449 who voluntarily took part in this study. Most of the participation aged 18 to 23 years' old which represent $76.2 \%(n=342)$ which holding variety class of driving license. Table 1 shows the characteristic of participation demographic data.

Table 1. Demographic data of respondents

\begin{tabular}{lc}
\hline Characteristic (N=449) & Frequency (percentage) \\
\hline Gender & $147(32.7)$ \\
Male & $302(67.3)$ \\
Female & \\
& \\
\hline Age range & $342(76.2)$ \\
$18-23$ & $92(20.5)$ \\
$24-29$ & $15(3.3)$ \\
$30-35$ & \\
& \\
\hline Area of living & $265(59.0)$ \\
Urban & $159(35.4)$ \\
Rural & $25(5.6)$ \\
Others & \\
& \\
\hline Race & $380(84.6)$ \\
Malay & $69(15.4)$ \\
Non-Malay & \\
& \\
\hline Religion & \\
Islam & $385(85.7)$ \\
Christian & $13(2.9)$ \\
Buddha & $37(8.2)$ \\
Hindu & $9(2.0)$ \\
Others & $5(1.1)$ \\
& \\
\hline & \\
\hline
\end{tabular}




\begin{tabular}{|c|c|}
\hline Characteristic $(\mathrm{N}=449)$ & Frequency (percentage) \\
\hline $\begin{array}{l}\text { Occupational status } \\
\text { Student } \\
\text { Worker } \\
\text { Others }\end{array}$ & $\begin{array}{c}365(81.3) \\
73(16.3) \\
11(2.4)\end{array}$ \\
\hline $\begin{array}{l}\text { Marital status } \\
\text { Single } \\
\text { Married } \\
\text { Others }\end{array}$ & $\begin{array}{c}411(91.5) \\
34(7.6) \\
4(0.9)\end{array}$ \\
\hline $\begin{array}{l}\text { Educational level } \\
\text { Foundation } \\
\text { Diploma } \\
\text { Degree } \\
\text { Master } \\
\text { PhD } \\
\text { Others }\end{array}$ & $\begin{array}{c}11(2.4) \\
86(19.2) \\
329(73.3) \\
5(1.1) \\
1(0.2) \\
17(3.8)\end{array}$ \\
\hline $\begin{array}{l}\text { Driving license class } \\
\text { B } \\
\text { B2 } \\
\text { D } \\
\text { Others } \\
\text { No license }\end{array}$ & $\begin{array}{c}14(3.1) \\
81(18.0) \\
337(75.1) \\
5(1.1) \\
12(2.7)\end{array}$ \\
\hline $\begin{array}{l}\text { Lifetime mileage (km per year) } \\
<10,000 \\
10,000-30,000 \\
>30,000 \\
\text { Others }\end{array}$ & $\begin{array}{c}376(83.7) \\
45(10.0) \\
15(3.3) \\
13(2.9)\end{array}$ \\
\hline $\begin{array}{l}\text { Driving purpose } \\
\text { Study } \\
\text { Working } \\
\text { Recreational } \\
\text { Others }\end{array}$ & $\begin{array}{r}149(33.2) \\
89(19.8) \\
56(12.5) \\
155(34.5)\end{array}$ \\
\hline $\begin{array}{l}\text { Types of vehicle } \\
\quad \text { Car } \\
\text { Motorcycle } \\
\text { Others }\end{array}$ & $\begin{array}{c}355(79.1) \\
88(19.6) \\
6(1.3)\end{array}$ \\
\hline $\begin{array}{l}\text { Involved in traffic accident } \\
\text { Yes } \\
\text { None }\end{array}$ & $\begin{array}{r}67(14.9) \\
382(85.1)\end{array}$ \\
\hline $\begin{array}{l}\text { Witness in traffic accident } \\
\text { Yes } \\
\text { None }\end{array}$ & $\begin{array}{l}130(29.0) \\
319(71.0)\end{array}$ \\
\hline $\begin{array}{l}\text { Types of personality } \\
\text { Type A } \\
\text { Type B } \\
\text { Others }\end{array}$ & $\begin{array}{r}70(15.6) \\
46(10.2) \\
333(74.2)\end{array}$ \\
\hline
\end{tabular}

Table 2 shows the mean, minimum and maximum score for each domain categories. The mean score for all six domains of ASDS46 as follows (45.29, 45.03, 21.29, 21.21, 12.23 and 13.51): 
Table 2. ASDS-46 scores for each domain.

\begin{tabular}{|c|c|c|c|c|c|c|}
\hline ASDS-46 Domain & D1 & D2 & D3 & D4 & D5 & D6 \\
\hline Mean & 45.29 & 45.03 & 21.29 & 21.21 & 12.23 & 13.51 \\
\hline Median & 46.00 & 45.00 & 21.00 & 21.00 & 12.00 & 13.00 \\
\hline Mode & 39.00 & 48.00 & 18.00 & 25.00 & 12.00 & 13.00 \\
\hline Std. Deviation & 10.27 & 6.47 & 3.91 & 3.10 & 2.95 & 2.69 \\
\hline Minimum & 13.00 & 24.00 & 6.00 & 5.00 & 4.00 & 4.00 \\
\hline Maximum & 65.00 & 60.00 & 30.00 & 25.00 & 20.00 & 20.00 \\
\hline Sum & 20330.00 & 20217.00 & 9560.00 & 9520.00 & 5491.00 & 6067.00 \\
\hline
\end{tabular}

Table 3 below represent the frequency and percentage of risk level obtain from the respondents. The highest and the lowest risk level between each domain had been bold in the table. The D5 (driving style) has the highest percentage of high risk while D1 (selfcompliant) has the biggest number of respondents which has low risk towards road traffic accident compared with other domains.

Table 3. Frequency and percentage of risk level in ASDS-46 for each domain.

\begin{tabular}{|c|c|c|c|c|c|c|}
\hline ASDS-46 Domain & D1 & D2 & D3 & D4 & D5 & D6 \\
\hline High risk & $221(49.2)$ & $234(52.1)$ & $228(50.8)$ & $227(50.6)$ & $247(55.0)$ & $243(54.1)$ \\
\hline Low risk & $228(50.8)$ & $215(47.9)$ & $221(49.2)$ & $222(49.4)$ & $202(45.0)$ & $206(45.9)$ \\
\hline
\end{tabular}

Table 4 shows that the majority group of the respondents falls within the mild internet addiction level which is $182(41 \%)$. The normal and moderate internet addiction levels are $141(31 \%)$ and $117(26 \%)$ respectively. However, the minority of internet addiction level is severe which is $9(2 \%)$.

Table 4. Frequency and percentage of IAT.

\begin{tabular}{llll}
\hline Level & Scoring Range & Frequency $(\mathrm{n})$ & Percentage (\%) \\
\hline Normal & $0-30$ & 141 & 31.4 \\
Mild & $31-49$ & 182 & 40.5 \\
Moderate & $50-79$ & 117 & 26.1 \\
Severe & $80-100$ & 9 & 2.0 \\
\hline
\end{tabular}

Table 5 presents the correlation table for the six domains of the ASDS-46 and IAT level that have been done by using Pearson Correlation Coefficient $(r)$. The table was calculated to test the null hypothesis $\left(\mathrm{H}_{0}\right)$ of no association between two variables. In order to determine the direction of these relationships are by the sign of the $r$ value $(+$ or -$)$. The evaluation showed that the correlation ranges from -0.095 to -0.225 which indicates that there was the negative correlation between these two variables. Therefore, the result indicates if one variable increase or have a high score, the other variable will decrease or low score. In particular, the degree of relationship, it can be identifying by using Sig or probability $(p)$ value of .05 or less, the Ho are failed to reject because there is the statistically significant relationship between these pairs of domains of ASDS-46 and IAT level. The significant correlations were labeled in bold.

According to Table 5, there were 3 domains that significantly correlated with each other. The correlations occur at the D1 (selfcompliant), D2 (self-confidence) and D4 (self-concern). Interestingly, the other three domains did not correlate with IAT level as there are no significant correlations between D3, D5 and D6 with IAT level $(r=-.064, p=.179),(r=.0 .073, p=.121)$ and $(r=-.014, p=.763)$. However, the $r$ values range between 0 until 0.3 , thus these 3 correlations had low correlation.

Table 5. Correlation table between the six domains of ASDS-46 and IAT.

\begin{tabular}{lllllll}
\hline ASDS-46 Domain & D1 & D2 & D3 & D4 & D5 & D6 \\
\hline IAT level & $-0.225^{\star \star}$ & $-0.111^{*}$ & -0.064 & $-0.095^{\star}$ & 0.073 & -0.014 \\
& & & & & & \\
\hline
\end{tabular}




\begin{tabular}{|c|c|c|c|c|c|c|}
\hline $\begin{array}{l}\text { Sig } \\
\text { (2 tailed) }\end{array}$ & .000 & .019 & .179 & .044 & .121 & .763 \\
\hline
\end{tabular}

${ }^{*}$ significant at $\alpha<0.05^{* *}$ significant at $\alpha<0.01$

\subsection{Discussion}

In demographic data, majority of the respondents $67.3 \%(n=302)$ are female, $76.2 \%(n=342)$ with age range 18 to 23 years' old, and $59.0 \%(n=265)$ live in the urban of living area. Most of them $85.7 \%(n=385)$ are Muslim, $84.6 \%(n=380)$ are Malay and $81.3 \%(n=365)$ are still studying in bachelor's degree which $73.3 \%(n=329)$ that lead to the biggest group of them are still single $91.5 \%(n=411)$. According to Pontes, Szabo, \& Griffiths (2015), the single person spends more time online per week on the internet compared to those who are in a relationship.

The D5 (driving style) has the highest percentage of high risk towards RTA. This result indicates that respondent who have a problem in changing their unsafe driving style will have high risk in RTA offenses and bad attitude towards safe driving. According to Masuri, Dahlan, Danis, \& Md Isa (2017), human behaviour provides the effect towards road traffic accident. Meanwhile, the highest frequency of internet addiction level of young adult is mild. It reveals that the respondents able to control their internet usage even though they may surf the web regularly. It is not a disorder for the youth to spend most of their time online because it is pleasant and amusing activity although some of them has the possibility to develop addictive behavior (Wallace, 2014).

The correlations for the six domains of the ASDS-46 and IAT level occur at the D1 (self-compliant), D2 (self-confidence) and D4 (self-concern). For D1, it proves that the respondents who have addicted towards internet, will use possible opportunity and space to violate road rules and safety. It is due to personality of type A as Nabi (2005) found that this type of person has been suspected to be associated to risky driving behaviour and lead to RTA. The reckless driving styles are dominant by the male gender of the young drivers and shows high levels of extroversion and thrill seeking (Taubman - Ben-Ari \& Yehiel, 2012). The personality of type A behaviour has an impact on driving (Šucha \& Seitl, 2011). For D2, it marks that the respondents who have high internet addiction level, also have high level of self-confidence to execute RTA offenses. This is because they are confidence in commit RTA as they have high confidence in terms of level of driving experience and have greater mileage. According to Scott-Parker, Watson, King, and Hyde (2011), the drivers who had their own cars have greater mileage and riskier driving because Wong, Chung, \& Huang (2010) found that they are extraordinarily confident and comfortable with unsafe driving. Meanwhile, for D4, the respondent who has internet addiction, has high hope and self-centred or morbid concern for oneself to ignore the road traffic legislation. They hope that road traffic accident does not occur and not worried if they do not follow the road and safety rules. This is because of the driving experience of the drivers to be as a predictor for the driving safety as they have skills- oriented driving and high ability in manoeuvre the car, even though they are having high exposure toward road violation (Lajunen \& Summala, 1995).

\subsection{Conclusion and Recommendations}

This study concludes that the association between internet addiction and risk level of attitude towards safe driving among young adults in Malaysia is an alarming issue and act as an indicator to all the road traffic offenses which can lead to road fatalities. The findings presented in this study may be served for further investigation and exploration of the internet uses in a secure way of safe driving.

A software may be created which will terminate the internet usage in the mobile phone as soon as the vehicle move. An application in the mobile phone with internet access can block the function of the mobile phone because it detects the vehicle move at certain speed as it can minimize the risk of distracted driving (Creaser, Edwards, Morris, \& Donath, 2015). The authorities should take a proactive action, develop and enforce the law of using a mobile phone while driving will be fined with large amount of payment or the vehicle will be confiscated and the driver will be prisoned. The possibility of using a mobile phone while driving increase when the traffic speed decreases yet this risky behaviour are less common when the fine is increases (Márquez, Cantillo, \& Arellana, 2015).

Fully understanding in particular of the factor of road traffic offense and consequences towards the road user enable to design appropriate intervention and strategies such as educational and enforcement campaigns to minimize the road traffic offenses and develop better road safety pattern in future. According to Benson, McLaughlin, and Giles (2015), the future campaigns and interventions that focusing on the moral aspect of behaviour should be held for all ages of drivers to reduce risky driving behaviour. Hence, this global issue able to be addressed and promote the good quality of life.

\section{Acknowledgements}

The highest appreciation goes to the Dr. Kimberly Young by allowing us to use the questionnaire. This study would like to thank to the Ministry of Higher Education Malaysia (MoHE), Royal Malaysia Police, SPAD, PROTON Professor office, Research Management Centre (RMC) Universiti Teknologi MARA (UiTM), CoRe Management Science, OPERA RIG, and all staff of the Faculty of Health Sciences UiTM Puncak Alam for continuous support in staff research and development. Thank you to our strategic partner, Majlis Bandaraya Petaling Jaya (MBPJ), and our future local and international collaborators: Universiti Malaysia Kelantan (UMK), Universiti Kuala Lumpur (UNiKL), Institut Teknologi Bandung (ITB), Asan City Council Republic of Korea, Bandung City Government, Indonesia, Qingyuan City Council, Guangdong Republic People of China and Seongbuk-gu City Council, Republic of Korea. Lastly, specially mentioned to our beloved friend and research team; Allahyarham Anniz Fazli Ibrahim Bajunid. This study was funded under LESTARI grant by UiTM - 
(600IRMI/Dana KCM 5/3/LESTARI (154/2017).

\section{References}

Ahmad, M. S., Zulkipli, Z. H., Ameer Batcha, W., Paiman, N. F., Mohd Faudzi, S. A., Othman, I., \& Osman, M. R. (2017). An Observational Study on Speeding among Malaysian Express Bus Drivers. Journal of the Society of Automotive Engineers Malaysia, 1(2), 94-102. Retrieved from http://journal.saemalaysia.org.my/issue/jsaem-12-ahmad/

Alavi, S. S., Maracy, M. R., Jannatifard, F., \& Eslami, M. (2011). The effect of psychiatric symptoms on the internet addiction disorder in Isfahan's University students. Journal of Research in Medical Sciences, 16(6), 793-800. Retrieved from https://www.ncbi.nlm.nih.gov/pmc/articles/PMC3214398/

Augustin, R. (2017, January 2). Over 46,000 fined for using mobile phones while driving. Free Malaysia Today [Kuala Lumpur]. Retrieved from http://www.freemalaysiatoday.com/category/nation/2017/01/02/over-46000-fined-for-using-mobile-phones-while-driving/

Benson, T., McLaughlin, M., \& Giles, M. (2015). The factors underlying the decision to text while driving. Transportation Research Part F: Traffic Psychology and Behaviour, 35, 85-100. doi:10.1016/j.trf.2015.10.013

Best, J. (2014, April 28). Driver dies after taking selfie behind the wheel before crashing into a truck. Mirror News Online. Retrieved from http://www.mirror.co.uk/news/world-news/driver-dies-after-taking-selfie-3469774

Błachnio, A., Przepiorka, A., Senol-Durak, E., Durak, M., \& Sherstyuk, L. (2017). The role of personality traits in Facebook and Internet addictions: A study on Polish, Turkish, and Ukrainian samples. Computers in Human Behavior, 68, 269-275. doi:10.1016/j.chb.2016.11.037

Chong Guan, N., Isa, S. M., Hashim, A. H., Pillai, S. K., \& Harbajan Singh, M. K. (2012). Validity of the Malay Version of the Internet Addiction Test. Asia Pacific Journal of Public Health, 27(2), NP2210-NP2219. doi:10.1177/1010539512447808

Cook, J. L., \& Jones, R. M. (2011). Texting and Accessing the Web While Driving: Traffic Citations and Crashes Among Young Adult Drivers. Traffic Injury Prevention, 12(6), 545-549. doi:10.1080/15389588.2011.620999

Creaser, J. I., Edwards, C. J., Morris, N. L., \& Donath, M. (2015). Are cellular phone blocking applications effective for novice teen drivers? Journal of Safety Research, 54, 75.e29-78. doi:10.1016/j.jsr.2015.06.014

Dieris-Hirche, J., Bottel, L., Bielefeld, M., Steinbüchel, T., Kehyayan, A., Dieris, B., \& Te Wildt, B. (2017). Media use and Internet addiction in adult depression: A casecontrol study. Computers in Human Behavior, 68, 96-103. doi:10.1016/j.chb.2016.11.016

Edelstein, S. (2012, November 21). Study says Internet use while driving is on the rise | Digital Trends. Retrieved from http://www.digitaltrends.com/cars/study-saysnearly-50-percent-of-drivers-under-age-30-use-the-internet-while-driving/

Gauld, C. S., Lewis, I., White, K. M., Fleiter, J. J., \& Watson, B. (2017). Smartphone use while driving: What factors predict young drivers' intentions to initiate, read, and respond to social interactive technology? Computers in Human Behavior, 76, 174-183. doi:10.1016/j.chb.2017.07.023

Harrison, M. A. (2011). College students' prevalence and perceptions of text messaging while driving. Accident Analysis \& Prevention, 43(4), 1516-1520. doi:10.1016/j.aap.2011.03.003

Insurance Information Institute. (2016, June). Distracted Driving | III. Retrieved from http://www.iii.org/issue-update/distracted-driving

Jabatan Perangkaan Malaysia. (2016, December 15). Buletin Perangkaan Sosial. Retrieved from https://www.dosm.gov.my/v1/index.php?r=column/pdfPrev\&id=N0tRL2RBK215djFyUnINR2FKWCtuUT09

Kamarudin, K. (2011). Memandu Sambil Berbual Di Telefon Tiada Jauh Beza Ketika Mabuk. Retrieved from Kementerian Perdagangan dalam Negeri, Koperasi dan Kepenggunaan website: http://kpdnkk.bernama.com/newsBm.php?id=580823

Kaur, M. (2015, December 9). Malaysians spend 12 hours daily on phone and online. New Straits Times [Kuala Lumpur]. Retrieved from https://www.nst.com.my/news/2015/12/116437/malaysians-spend-12-hours-daily-phone-and-online

Khati, I., Hours, M., Charnay, P., Chossegros, L., Tardy, H., Nhac-Vu, H., ... Laumon, B. (2013). Quality of life one year after a road accident. Journal of Trauma and Acute Care Surgery, 74(1), 301-311. doi:10.1097/ta.0b013e318270d967

Lajunen, T., \& Summala, H. (1995). Driving experience, personality, and skill and safety-motive dimensions in drivers' self-assessments. Personality and Individual Differences, 19(3), 307-318. doi:10.1016/0191-8869(95)00068-h

Marlin. (2008). Penggunaan Internet Dalam Pencarian Maklumat di Kalangan Pelajar-Pelajar Indonesia di Universiti Malaya (Master's thesis, Universiti Malaya, Kuala Lumpur, Malaysia). Retrieved from http://repository.um.edu.my/237/1/Penggunaan\%20internet\%20dalam\%20pencarian\%20maklumat.pdf

Masuri, M. G., Dahlan, A., Danis, A., \& Md Isa, K. A. (2015). Public Participation in Shaping Better Road Users in Malaysia. Procedia - Social and Behavioral Sciences, 168, 341-348. doi: 10.1016/j.sbspro.2014.10.239

Masuri, M. G., Dahlan, A., Danis, A., \& Md Isa, K. A. (2016). Attitude towards Safe Driving Scale (ASDS) As a Future Predictor in Determining a Young Adult Quality of Life: Part I. Procedia - Social and Behavioral Sciences, 234, 390-397. doi:10.1016/j.sbspro.2016.10.256

Masuri, M. G., Dahlan, A., Danis, A., \& Md Isa, K. A. (2017). Attitude towards Safe Driving Scale (ASDS-46) as a Future Predictor in Determining a Young Adult Quality of Life: Part II. Environment-Behaviour Proceedings Journal, 2(5), 363. doi:10.21834/e-bpj.v2i5.705 
Md Isa, K. A., Masuri, M. G., Abd Aziz, N. A., Isa, N. N., Hazali, N., Tahir, M. P., ... Fansuri, H. (2012). Mobile Phone Usage Behaviour while Driving among Educated Young Adults in the Urban University. Procedia - Social and Behavioral Sciences, 36, 414-420. doi:10.1016/j.sbspro.2012.03.045

Mendoza, M. (2015, December 8). Report: 1 in 5 drivers admit to snapping selfies, taking photos while driving. San Antonio Express News. Retrieved from http://www.mysanantonio.com/lifestyle/trends-style/article/One-in-five-drivers-ares-snapping-selfies-and-6683182.php

Murad, D. (2014, February 22). Malaysia has 17th most dangerous roads in the world, according to Michigan university research. The Star [Petaling Jaya]. Retrieved from http://www.thestar.com.my/news/nation/2014/02/22/nations-with-deadliest-roads-malaysia-17th/

Márquez, L., Cantillo, V., \& Arellana, J. (2015). Mobile phone use while driving: A hybrid modeling approach. Accident Analysis \& Prevention, 78, 73-80. doi:10.1016/j.aap.2015.02.016

Nabi, H. (2005). Type A Behavior Pattern, Risky Driving Behaviors, and Serious Road Traffic Accidents: A Prospective Study of the GAZEL Cohort. American Journal of Epidemiology, 161(9), 864-870. doi:10.1093/aje/kwi110

Nasa, A. (2014, July 9). Malaysia ranked 20th in road deaths. New Straits Times [Kuala Lumpur]. Retrieved from https://www.nst.com.my/news/2015/09/malaysia-ranked20th-road-deaths

Oluwole, A. M., Abdul Rani, M. R., \& Rohani, J. M. (2015). Commercial Bus Accident Analysis through Accident Database. Journal of Transport System Engineering, 2(1), 07-14. Retrieved from www.jtse.utm.my/index.php/jtse/article/download/33/24

Penggunaan telefon bimbit antara punca utama kemalangan jalan raya. (2016, June 25). Astro Awani [Bentong]. Retrieved from http://www.astroawani.com/beritamalaysia/penggunaan-telefon-bimbit-antara-punca-utama-kemalangan-jalan-raya-109199

Pontes, H. M., Szabo, A., \& Griffiths, M. D. (2015). The impact of Internet-based specific activities on the perceptions of Internet addiction, quality of life, and excessive usage: A cross-sectional study. Addictive Behaviors Reports, 1, 19-25. doi:10.1016/j.abrep.2015.03.002

Pöysti, L., Rajalin, S., \& Summala, H. (2005). Factors influencing the use of cellular (mobile) phone during driving and hazards while using it. Accident Analysis \& Prevention, 37(1), 47-51. doi:10.1016/j.aap.2004.06.003

Scott-Parker, B., Watson, B., King, M. J., \& Hyde, M. K. (2011). Mileage, Car Ownership, Experience of Punishment Avoidance, and the Risky Driving of Young Drivers. Traffic Injury Prevention, 12(6), 559-567. doi:10.1080/15389588.2011.621000

Shaw, M., \& Black, D. W. (2008). Internet Addiction. CNS Drugs, 22(5), 353-365. doi:10.2165/00023210-200822050-00001

Sitheravellu, C. S. (2017, January 1). Safety campaigns failing. New Straights Times[Seremban]. Retrieved from https:/www.nst.com.my/news/2017/01/201031/safetycampaigns-failing

Šucha, M., \& Seitl, M. (2011). The Role of Personality Qualities in Driving. Transactions on Transport Sciences, 4(4), 225-232. doi:10.2478/v10158-011-0019-3

Taubman - Ben-Ari, O., \& Yehiel, D. (2012). Driving styles and their associations with personality and motivation. Accident Analysis \& Prevention, 45, 416-422. doi:10.1016/j.aap.2011.08.007

Tournier, C., Hours, M., Charnay, P., Chossegros, L., \& Tardy, H. (2016). Five years after the accident, whiplash casualties still have poorer quality of life in the physical domain than other mildly injured casualties: analysis of the ESPARR cohort. BMC Public Health, 16(1). doi:10.1186/s12889-015-2647-8

Wallace, P. (2014). Internet addiction disorder and youth. EMBO Reports, 15(1), 12-16. doi:10.1002/embr.201338222

Weinstein, A., \& Lejoyeux, M. (2010). Internet Addiction or Excessive Internet Use. The American Journal of Drug and Alcohol Abuse, 36(5), $277-283$. doi:10.3109/00952990.2010.491880

Weller, J. A., Shackleford, C., Dieckmann, N., \& Slovic, P. (2013). Possession attachment predicts cell phone use while driving. Health Psychology, 32(4), 379-387. doi:10.1037/a0029265

Wong, J., Chung, Y., \& Huang, S. (2010). Determinants behind young motorcyclists' risky riding behavior. Accident Analysis \& Prevention, 42(1), 275-281. doi:10.1016/.aap.2009.08.004

World Health Organization. (2015). WHO | Global status report on road safety 2015. Retrieved from World Health Organization website: http://www.who.int/violence_injury_prevention/road_safety_status/2015/en/ 